\title{
Environmental Utilization of Indonesian Language Learning Media
}

\author{
Abrar Ridha/18016059 \\ abrar180600@gmail.com
}

Utilization of the environment is one of the good learning media to be applied in the learning process, because it can foster students' interest and enthusiasm. This can be applied in Indonesian language subjects. Because students can observe what is in the environment and make what students see as a source of inspiration to make a literary work. According to Rivers (in Ramadhan et al, 2019), as language teachers, we are the luckiest teachers, all subjects are ours. Whatever our students want to communicate, whatever they want to read, is our subject matter. According to Hauchild, Poltavthenko and Stoller (in Ramadan et al, 2019), language teachers are in a unique position to promote environmental awareness.

According to Mitsuki and Lai (in Ramadhan et al, 2019), all over the world, everyone faces serious environmental problems, such as global warming, acid rain, destruction of the ozone layer, environmental pollution, natural damage and loss of biodiversity can threaten the lives of generations. to come. Environmental problems are caused by careless and intensive human activity in natural areas to improve their quality of life. A more threatening aspect is the unconscious influence of humans on their environment. Environmental degradation produces an ecological crisis that will cause a series of problems with natural resources, climate, pollution, food and the economy. People living today are faced with environmental problems that cause natural disasters.

According to Buldur and Omeroglu (in Ramadhan et al, 2019), environmental education is important to increase students' attitudes and awareness of the environment. Environmental education should be designed to contribute to the cognitive, emotional, linguistic and psychomotor development of students, and enable them to develop positive attitudes towards the environment.In addition, teachers must also develop students' abilities to understand, criticize, and participate rationally in any discourse about environmental problems. . According to Unyar and Ensar (in Ramadhan et al, 2019), using learning material in text learning can trigger student interest in learning language and this has implications for increasing students' knowledge of the environment.

According to Jacobs G.M and Cates K (in Ramadhan et al, 2019), the purpose of environmental education is to make students participate in protecting the environment, to make students participate in protecting the environment. According to Kollmuss A and Agyeman J, Schultz PW, Shriver C, Tabanico JJ, and KhazianA M, Xehua Z, and ÇokçaliskanH and ÇelikÖ (in Ramadhan et al, 2019), so that students participate in 
protecting the environment, it is important to develop knowledge about the environment, awareness environment and changes in behavior towards the environment. Individuals should be encouraged not to view the environment as something that must be exploited for their purposes, but as a valuable asset worthy of protection for human survival.

According to Mitsuki, Nkwetisma and Nieblas Oritz (in Ramadhan et al, 2019), that everyone has the same responsibility to solve this problem. Because environmental damage is not caused by a particular place, but can come from the surrounding environment. The damage affects not only future lives, but also current. All over the world many methods have been applied to solve environmental problems, such as government policies, appeals to the public, the nature-loving movement, and strengthening government regulations. However, this method is not effective enough to reduce environmental problems. Developing individuals who are aware and responsible for the environment is necessary to overcome this problem so that the environment is sustainable and the quality of life is better.

According to Obasoro, Olinloye, and Ilensami (in Ramadhan et al, 2019), students need to have good experience in understanding and coping with every change in global and community environment. According to Begman B, G (in Ramadhan et al, 2019), related to that The teacher also has an important role in teaching environmental material to students. Teachers in environmental material taught by the teacher make the teacher the right model in understanding environmental material. In addition, students also play an important role in responding and applying about their understanding in studying environmental material. Because without the application of students, learning environmental material in the learning provided by the teacher, the learning objectives will not be achieved.

Lai (in Ramadhan et al, 2019) said that environmental problems are inherently inseparable from environmental awareness, values, and people's attitudes. This prompted countries to start assessing environmental education. Environmental education is a process to build a human population in a world who is aware and cares about the total environment (as a whole) and all the problems associated with it, and people who have the knowledge, skills, attitudes and behavior, motivation and commitment to work together, both individually or collectively, to be able to solve various current environmental problems, and prevent new problems from arising (UNESCO, Tbilisi Declaration, 1977).

From the data generated regarding environmental material in Indonesian language learning that can be applied in everyday life, 54.1\% strongly agree and $45.9 \%$ agree. Environment-based learning aims to make students participate in protecting the environment, $54.1 \%$ strongly agree and $45.9 \%$ agree. In learning Indonesian, environmental material is 
easier to exemplify than scientific theory. $59.5 \%$ strongly agreed and $40.5 \%$ agreed. Indonesian language learning material regarding the environment is an interesting and diverse topic to be taught, $43.2 \%$ said they strongly agreed and $56.7 \%$ agreed. Having knowledge about the environment in learning Indonesian can expand knowledge and writing skills, $56.8 \%$ strongly agree, $40.5 \%$ agree and $2.7 \%$ disagree. Environmental materials make it easier for students to understand Indonesian language learning, $43.2 \%$ strongly agree, $51.4 \%$ agree and 5.4\% disagree. Environmental material in Indonesian language learning is not important, $21.6 \%$ strongly agree, $24.3 \%$ agree, $10.8 \%$ disagree and $43.2 \%$ disagree. The environment can be used as a source of learning Indonesian, $51.4 \%$ strongly agree and $48.6 \%$ agree. The environment as a source of learning Indonesian is richer because the environment that can be studied is diverse, $40.5 \%$ strongly agree and $59.5 \%$ agree. Utilization of the environment is a good Indonesian language learning medium to be applied in the learning process, $40.5 \%$ strongly agree and $59.5 \%$ agree.

From the results of filling out the questionnaire that the author has done, it can be concluded that students and students agree that the use of the environment is one of the good learning media. The use of the environment as a learning medium is more meaningful because students are faced directly with actual events and circumstances naturally, so that it is more real, more factual, and the truth can be justified. Besides that, the teacher also hopes that students will be more familiar with the environment so that they foster a sense of love for their surroundings. 


\section{Reference}

Bergman, B.G. (2016). Assessing impacts of locally designed environmental education projects on students' environmental attitudes, awareness, and intention to act Environmental Education Reseach 22(4) 480-503

Buldur, A. and Ömeroglu, E. (2018). An examination of the relationship between pre-school children's and their teacher' attitute and awareness towards the environment Journal of Education and Learning 7(2) 221-9.

Hauchild, S., Poltavthenko, E. And Stoller, F. L. (2012. Going green: Menging environmental education ang language instruction English Teaching Forum Number2 $2-13$

Jacobs G M and Cates K.(2012). Global education in second language and teaching International Journal of Physical and Social Sciences 2 1-22

Kollmuss A and Agyeman J. (2002). Mind the gap: Why do people act enviconmentally andwhat are the barriers to pro-environmental behavior Environmental Education Research 239-60

Lai, C.S. (2018). A study of fifth graders' environmental learning outcomes in Taipei International Journal of Research in Education and Science4(1) 252-61

Mitsuki I. (2017) Beyond the limitations of environmental education in Japan Educational Studies in Japan: International Yearbook 3-14

Nieblas-Ortiz E C, Acrcos-Vega J L and Sevilla-Garcia J J 2017 The construction of an environmental management model based on sustainability indicators on a higher education institution in Mexico Higher Education Studies 715-22

Nkwetisma C M.(2011) EFL/ESL and environmental education: towards an eco applied linguistic awareness in Cameroon World Journal of Education 1(1) 110-18

Ramadhan, S., Sukma, E., \& Indriyani, V. (2019). Environmental education and disaster mitigation through language learning. IOP Conference Series: Earth and Environmental Science, 314

Obasoro C B,Olinloye O A,and Illansami A A.2013 The importance of environmental education to secondary education level in Akure South local goverment area, Ondo State Nigeria,Africa Research Reviiew 7 (4) 298-306

Uyar Y and Ensar F 2016 Does mother tongue education support development of environmental literacy in Turkey? An analysis of Turkish course book International Journal of Environmental \& Science Education 11(1) 1-8 